\title{
Amycolatopsis echigonensis sp. nov. and Amycolatopsis niigatensis sp. nov., novel actinomycetes isolated from a filtration substrate
}

Correspondence

Linxian Ding

linxian@iam.u-tokyo.ac.jp

\author{
Linxian Ding, Taketo Hirose and Akira Yokota
}

\author{
Laboratory of Bioresources, Institute of Molecular and Cellular Biosciences, The University of Tokyo, \\ Yayoi, Bunkyo-ku, Tokyo 113-0032, Japan
}

The genus Amycolatopsis was established by Lechevalier et al. (1986) and was assigned to the family Pseudonocardiaceae (Embley et al., 1988; Warwick et al., 1994). The principal characteristics of this genus are the presence of a type IV cell wall (meso-diaminopimelic acid and cell-wall sugars consisting of arabinose and galactose; Lechevalier \& Lechevalier, 1970; Lechevalier et al., 1986) and MK-9 $\left(\mathrm{H}_{4}\right)$ menaquinones and the absence of mycolic acids. During the first 13 years of its existence, only 10 novel species were described for this genus, but, since 2000, many novel species have been described from soil, fresh water, human and animal clinical sources, natural caves, prairie soil and other natural areas. At the time of writing, the genus contains 34 species (as well as four subspecies).

In this investigation, we describe two actinomycetes, $\mathrm{LC} 2^{\mathrm{T}}$ and $\mathrm{LC} 11^{\mathrm{T}}$, which were isolated from a filtration substrate composed of volcanic soil. They are moderately thermophilic actinomycetes that can grow at $45{ }^{\circ} \mathrm{C}$. Genotypic and phenotypic analyses indicated that these isolates should be classified within two novel species of the genus Amycolatopsis.

We used a filtration substrate as the substrate for the isolation of bacterial strains on NY medium (1.6 g nutrient broth, $0.5 \mathrm{~g}$ yeast extract, $1000 \mathrm{ml}$ deionized water and $1.5 \%$ agar, $\mathrm{pH} 7.0)$ with cycloheximide $\left(0.05 \mathrm{~g} \mathrm{l}^{-1}\right)$ and kabicidin $\left(0.1 \mathrm{~g} \mathrm{l}^{-1}\right)$. All of the isolates were maintained on NY medium or oatmeal agar and incubated at $27^{\circ} \mathrm{C}$.

The GenBank/EMBL/DDBJ accession numbers for the 16S rRNA gene sequences of strains $L C 2^{\top}$ and $L C 11^{\top}$ are $A B 248535$ and $A B 248537$.
Determination of the optimum temperature for growth and $\mathrm{pH}$ tolerance was carried out by incubating in both nutrient broth and nutrient agar. $\mathrm{NaCl}$ tolerance was determined in nutrient broth amended with 3, 5 and $7 \%$ $\mathrm{NaCl}$ and incubated at $27{ }^{\circ} \mathrm{C}$. Air-dried smears prepared at $48 \mathrm{~h}$ intervals were Gram-stained to determine the Gram reaction, and investigation of the cell morphology was done after incubating for 2 weeks. Biochemical tests were performed with API 50CH, API ZYM and API CORYNE strips (bioMérieux) according to the manufacturer's instructions.

Genomic DNA preparation and PCR amplification of the 16S rRNA gene were performed as described previously by Ding \& Yokota (2002, 2004). Nucleotide sequences were obtained automatically using an Applied Biosystems DNA sequencer (model 377) and software provided by the manufacturer. Alignment was performed using CLUSTAL_X version 1.83 (Thompson et al., 1997). Phylogenetic trees were constructed by the neighbour-joining method (Saitou \& Nei, 1987) and the maximum-likelihood method (Felsenstein, 1981) and parsimony analysis based on 1348 nucleotides present in all strains. The evolutionary distance matrix was calculated using Kimura's two-parameter method (Kimura, 1980). The topology of the phylogenetic tree was evaluated by bootstrap analysis with 1000 sampling replications according to the method of Felsenstein (1985). The PHYLIP package (version 3.5c; Felsenstein, 1993) was used for all phylogenetic analyses.

Genomic DNA was prepared using a method described previously (Sambrook et al., 1989). The G+C content of 
the DNA was determined by HPLC (Mesbah et al., 1989). DNA-DNA relatedness experiments were performed by a modification of the microplate method of Ezaki et al. (1989), using photobiotin-labelled DNA and microdilution wells, as described by Willems et al. (2001). The DNADNA hybridization temperature was $55{ }^{\circ} \mathrm{C}$.

The isomeric form of the diaminopimelic acid was determined by TLC from whole-cell hydrolysates using the method of Staneck \& Roberts (1974). The whole-cell sugar composition was determined by TLC as described by Staneck \& Roberts (1974), Hasegawa et al. (1983) and Lechevalier \& Lechevalier (1980). Analysis of menaquinones was carried out according to the methods of Minnikin et al. (1984) and Kroppenstedt (1985). Mycolic acids were examined by the acid methanolysis method of Minnikin et al. (1980) and Yano et al. (1972). The strains were incubated on TSBA medium for $48 \mathrm{~h}$ at $30{ }^{\circ} \mathrm{C}$. Fatty acid methyl esters were obtained from the cells by saponification, methylation and extraction. Analysis by GC was controlled by MIS software (Microbial ID Inc.). The peaks were automatically integrated and identified by the Microbial Identification software package (Sasser, 1990).
The almost-complete 16S rRNA gene sequences of strains $\mathrm{LC}^{\mathrm{T}}(1473 \mathrm{nt})$ and $\mathrm{LC}^{1} 1^{\mathrm{T}}$ (1472 nt) were determined in this study. Database sequences for other members of the genus Amycolatopsis were obtained from DDBJ/EMBL/ GenBank for use in comparative analyses, and the phylogenetic tree was constructed. 16S rRNA gene sequence comparisons showed clearly that isolates $\mathrm{LC}^{\mathrm{T}}$ and $\mathrm{LC} 11^{\mathrm{T}}$ are members of the genus Amycolatopsis. Fig. 1 shows that these two isolates, Amycolatopsis rubida, Amycolatopsis albidoflavus and Amycolatopsis benzoatilytica formed a single cluster, and the sequence similarity between strains $\mathrm{LC} 2^{\mathrm{T}}$ and the type strains of $A$. rubida, A. albidoflavus, $A$. benzoatilytica and $\mathrm{LC}_{1}{ }^{\mathrm{T}}$ was $97.6,98.1,97.9$ and $96.4 \%$, respectively, while the sequence similarity of strains $\mathrm{LC} 11^{\mathrm{T}}$ and the type strains of A. rubida, A. albidoflavus and A. benzoatilytica was respectively $97.8,98.2$ and $96.1 \%$. These results suggest that strains $\mathrm{LC}^{\mathrm{T}}$ and $\mathrm{LC}_{1}{ }^{\mathrm{T}}$ belong to two genetically distinct Amycolatopsis species, which are not closely related to A. rubida, A. albidoflavus and A. benzoatilytica. Furthermore, chromosomal DNA-DNA hybridization studies were performed to establish whether isolates $\mathrm{LC}^{\mathrm{T}}$ and $\mathrm{LC} 11^{\mathrm{T}}$ represent distinct species. Strain $\mathrm{LC} 2^{\mathrm{T}}$

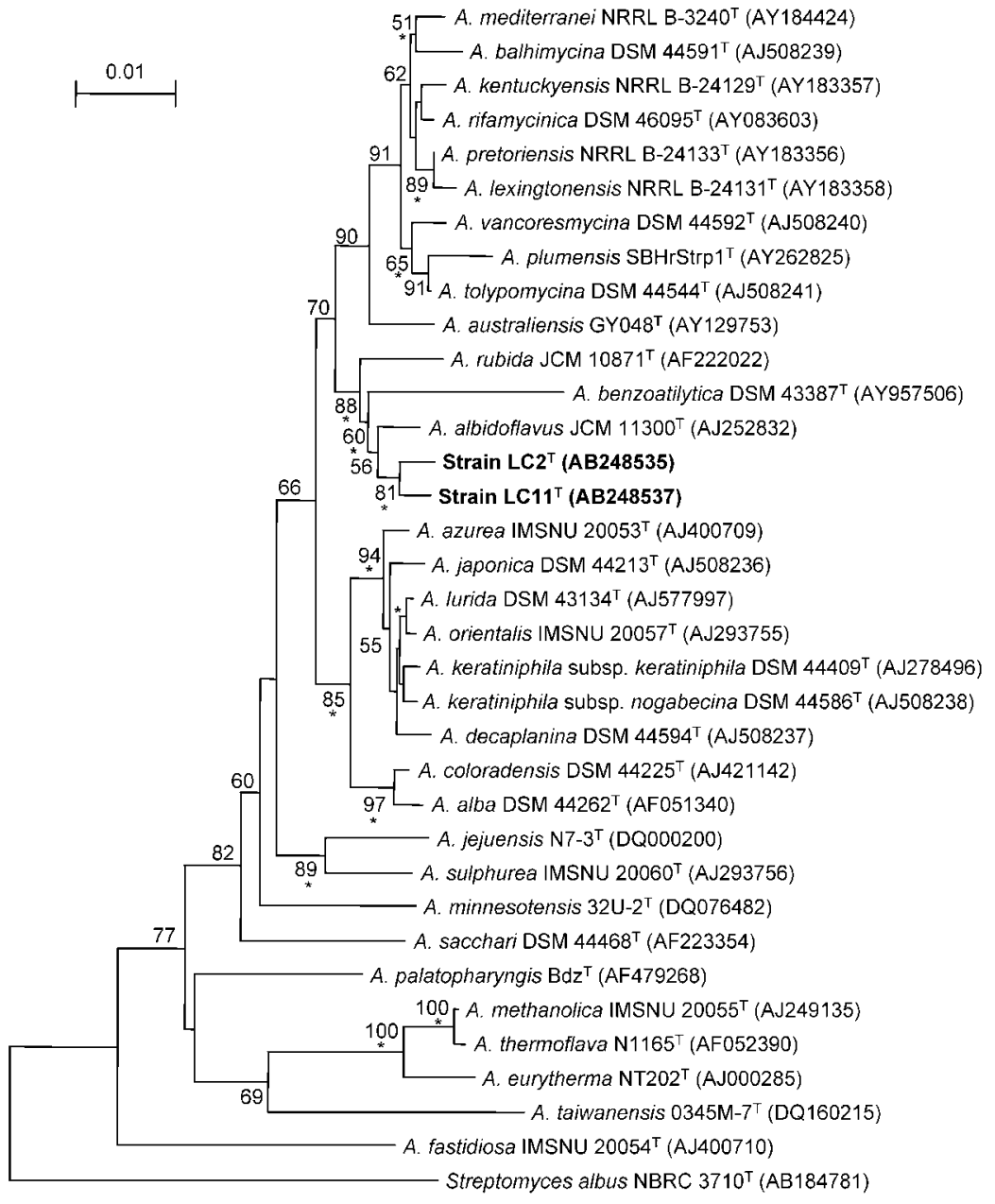

Fig. 1. Neighbour-joining tree based on almost complete $16 \mathrm{~S}$ rRNA gene sequences showing the phylogenetic position of strains $\mathrm{LC}_{2}{ }^{\top}$ and $\mathrm{LC}_{1} 1^{\top}$ within the radiation of Amycolatopsis species. Asterisks indicate branches of the tree that were also found using the maximum-likelihood (Felsenstein, 1981) treeing algorithm. Numbers at nodes indicate percentage levels of bootstrap support based on a neighbour-joining analysis of 1000 resampled datasets; only values over $50 \%$ are given. Bar, 0.01 nucleotide substitution per nucleotide position. 
Table 1. Differential phenotypic characteristics of the novel species of the genus Amycolatopsis

Data for reference strains were taken from Lee \& Hah (2001) (A. albidoflavus), Huang et al. (2001) (A. rubida) and Majumdar et al. (2006) (A. benzoatilytica). +, Positive; $(+)$, weakly positive; - , negative; ND, no data.

\begin{tabular}{|c|c|c|c|c|c|}
\hline Characteristic & Strain $\mathrm{LC}^{\mathrm{T}}$ & Strain $\mathrm{LC} 11^{\mathrm{T}}$ & 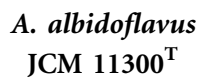 & $\begin{array}{c}\text { A. rubida } \\
\text { JCM } 10871^{\mathrm{T}}\end{array}$ & $\begin{array}{l}\text { A. benzoatilytica } \\
\text { DSM } 43387^{\mathrm{T}}\end{array}$ \\
\hline Colony colour ${ }^{\star}$ & W/LY & $\mathrm{W}, \mathrm{Y} / \mathrm{PB}$ & $\mathrm{W} / \mathrm{Y}$ & $\mathrm{w} / \mathrm{Y}$ & CC \\
\hline $\mathrm{pH}$ range for growth & $6-11$ & $6-11$ & ND & $\mathrm{ND}$ & $5-10$ \\
\hline Growth in the presence of $\mathrm{NaCl}(\%, w / v)$ & $3-7$ & $3-7$ & 7 & 7 & 5 \\
\hline \multicolumn{6}{|l|}{ Acid produced from: } \\
\hline D-Lactose & + & - & + & - & + \\
\hline D-Mannose & - & - & + & ND & + \\
\hline D-Mannitol & - & + & $(+)$ & + & - \\
\hline D-Sorbitol & - & $(+)$ & - & - & - \\
\hline Nitrate reductase & + & - & + & ND & ND \\
\hline
\end{tabular}

${ }^{\star} \mathrm{CC}$, Cream-coloured; LY, light yellow; PB, purple-brown; w, white; Y, yellow.

displayed low levels of DNA-DNA reassociation with $A$. albidoflavus JCM $11300^{\mathrm{T}}$ (44.7-48.3\%), A. rubida JCM $10871^{\mathrm{T}}(39.0-44.1 \%)$ and strain $\mathrm{LC} 11^{\mathrm{T}}(58.0-62.1 \%)$; also, strain $\mathrm{LC} 11^{\mathrm{T}}$ displayed low levels of DNA-DNA reassociation with A. albidoflavus JCM $11300^{\mathrm{T}}(32.8-34.4 \%)$ and $A$. rubida JCM $10871^{\mathrm{T}}(28.3-35.3 \%)$. These results are below the cut-off point recommended for the circumscription of bacterial genomic species by Wayne et al. (1987), and confirm the separation of isolates $\mathrm{LC}^{\mathrm{T}}$ and $\mathrm{LC} 11^{\mathrm{T}}$ from A. albidoflavus, $A$. rubida and A. benzoatilytica.

Table 2. Comparison of chemotaxonomic and genetic characteristics among the novel isolates and related Amycolatopsis species Data for reference strains were taken from Lee \& Hah (2001) (A. albidoflavus), Huang et al. (2001) (A. rubida) and Majumdar et al. (2006) (A. benzoatilytica).

\begin{tabular}{|c|c|c|c|c|c|}
\hline Characteristic & Strain $L C 2^{\mathrm{T}}$ & Strain $\mathrm{LC} 1^{\mathrm{T}}$ & $\begin{array}{l}\text { A. albidoflavus } \\
\mathrm{JCM}^{11300^{\mathrm{T}}}\end{array}$ & $\begin{array}{c}\text { A. rubida } \\
\text { JCM } 10871^{\mathrm{T}}\end{array}$ & $\begin{array}{c}\text { A. benzoatilytica } \\
\text { DSM } 43387^{\mathrm{T}}\end{array}$ \\
\hline \multicolumn{6}{|l|}{ Fatty acid (\%) } \\
\hline $\mathrm{C}_{14: 0}$ & 0.4 & 0.4 & 1.1 & 0.2 & 0.5 \\
\hline iso- $\mathrm{C}_{15: 0}$ & 7.0 & 9.3 & 8.7 & 22.7 & 6.8 \\
\hline anteiso- $\mathrm{C}_{15: 0}$ & 16.7 & 7.7 & & 5.9 & 3.0 \\
\hline $\mathrm{C}_{15: 1} \omega 6 c$ & 3.6 & & 2.3 & 1.6 & 12.8 \\
\hline iso- $\mathrm{C}_{16: 0}$ & 31.9 & 40.0 & 26.1 & 11.2 & 12.8 \\
\hline $\mathrm{C}_{16: 0}$ & 2.5 & 2.1 & 10.2 & 5.6 & 5.2 \\
\hline iso- $\mathrm{C}_{16: 1} \mathrm{H}$ & 1.3 & 2.6 & & & 0.2 \\
\hline iso- $\mathrm{C}_{17: 0}$ & 1.1 & 1.6 & 1.6 & 8.1 & 0.4 \\
\hline anteiso- $\mathrm{C}_{17: 0}$ & 6.9 & 6.9 & & 12.4 & 0.8 \\
\hline $\mathrm{C}_{18: 0}$ & & & 6.2 & & 0.4 \\
\hline Summed feature $3^{\star}$ & 4.5 & 5.3 & & 11.6 & 6.8 \\
\hline Major quinone & MK-9 $\left(\mathrm{H}_{4}\right)$ & MK-9 $\left(\mathrm{H}_{4}\right)$ & MK-9 $\left(\mathrm{H}_{4}\right)$ & MK-9 $\left(\mathrm{H}_{6}\right)$ & ND \\
\hline DNA G $+C$ content $(\mathrm{mol} \%)$ & 72.7 & 72.4 & 68.5 & 67.4 & $\mathrm{ND}$ \\
\hline
\end{tabular}

${ }^{*}$ Summed feature 3 contains $\mathrm{C}_{16: 1} \omega 7 c$ and/or iso- $\mathrm{C}_{15: 0}$ 2-OH. 
The classification of isolates $\mathrm{LC}^{\mathrm{T}}$ and $\mathrm{LC} 11^{\mathrm{T}}$ within the genus Amycolatopsis is supported by phenotypic, morphological and biochemical characteristics. Differential morphological and physiological characteristics are shown in Table 1. Both isolates are Gram-positive, aerobic, catalase-positive and oxidase-negative. Results of chemotaxonomic analysis of the isoprenoid menaquinone, fatty acid compositions and DNA G $+C$ content of isolates $\mathrm{LC}^{\mathrm{T}}$ and $\mathrm{LC}_{1}{ }^{\mathrm{T}}$ are shown in Table 2. The major isoprenoid menaquinone was MK-9 $\left(\mathrm{H}_{4}\right)$. The major cellular fatty acid was iso- $\mathrm{C}_{16: 0}$ (31.9 and $40.0 \%$ of the total in strains $\mathrm{LC}_{2}{ }^{\mathrm{T}}$ and $\mathrm{LC}_{11}{ }^{\mathrm{T}}$ ), and other fatty acids (over $5 \%$ of the total) included iso- $\mathrm{C}_{14: 0}$, iso- $\mathrm{C}_{15: 0}$, anteiso- $\mathrm{C}_{15: 0}, \mathrm{C}_{15: 0}$, anteiso$\mathrm{C}_{17: 0}$ and $\mathrm{C}_{17: 1} \omega 6 c$. The isolates contained meso-diaminopimelic acid as the cell-wall diamino acid and arabinose and galactose as major whole-cell sugars (type IV cell wall, according to Lechevalier \& Lechevalier, 1970). The strains did not contain mycolic acids. Other morphological and physiological characteristics are listed in the species descriptions.

On the basis of the phenotypic, chemotaxonomic and phylogenetic data, strains $\mathrm{LC} 2^{\mathrm{T}}$ and $\mathrm{LC} 11^{\mathrm{T}}$ merit recognition as representatives of novel species of the genus Amycolatopsis. We propose the names Amycolatopsis echigonensis sp. nov. and Amycolatopsis niigatensis sp. nov. for these taxa.

\section{Description of Amycolatopsis echigonensis sp. nov.}

Amycolatopsis echigonensis (e.chi.go.nen'sis. N.L. fem. adj. echigonensis referring to Echigo, the old name of Niigata Prefecture, Japan, from where the type strain was isolated).

Cells are aerobic, non-motile and Gram-positive and form a well-developed aerial and vegetative mycelium. The aerial mycelium is white and the vegetative mycelium is light yellow. The temperature range for growth is $5-45{ }^{\circ} \mathrm{C}$ and the optimum temperature for growth is $30{ }^{\circ} \mathrm{C}$. Grows on medium containing 3-7\% NaCl. The $\mathrm{pH}$ range for growth is 6-11, and the optimum is $\mathrm{pH} 9$. Catalase-positive and oxidase-negative. Acid is produced from D-xylose, D-galactose, L-rhamnose, inositol and D-lactose. Production of acid from erythritol, D-adonitol and D-glucose is weak. Using the API CORYNE and API ZYM systems, positive reactions are observed for nitrate reductase, pyrazinamidase, $\alpha$-glucosidase, $\beta$-glucuronidase, $\beta$-galactosidase, urease, gelatin hydrolysis, esterase (C4), esterase lipase (C8), leucine arylamidase, valine arylamidase, cystine arylamidase, trypsin, acid phosphatase, $\alpha$-galactosidase, alkaline phosphatase, $N$-acetyl- $\beta$ glucosaminidase, naphthol-AS-BI-phosphohydrolase and $\alpha$-mannosidase. No activity is detected for $\beta$-glucosidase, lipase (C14) or $\alpha$-fucosidase; pyrrolidonyl arylamidase and $\alpha$-chymotrypsin activities are weak. The predominant fatty acid is iso- $\mathrm{C}_{16: 0}$. The major menaquinone is MK-9 $\left(\mathrm{H}_{4}\right)$. The $\mathrm{G}+\mathrm{C}$ content of the type strain is $72.7 \mathrm{~mol} \%$.

The type strain is strain $\mathrm{LC}^{\mathrm{T}}\left(=\mathrm{IAM} 15387^{\mathrm{T}}=\mathrm{CCTCC}\right.$ $\mathrm{AB} 206019^{\mathrm{T}}$ ), which was isolated from a filtration substrate made from volcanic soil, Niigata, Japan.

\section{Description of Amycolatopsis niigatensis sp. nov.}

Amycolatopsis niigatensis (ni.i.ga.ten'sis. N.L. fem. adj. niigatensis referring to Niigata Prefecture, Japan, from where the type strain was isolated).

Cells are aerobic, non-motile and Gram-positive and form a well-developed aerial and vegetative mycelium. The aerial mycelium is white or light yellow; the vegetative mycelium is purple or purple-brown. The temperature range for growth is $5-45{ }^{\circ} \mathrm{C}$ and the optimum temperature for growth is $30{ }^{\circ} \mathrm{C}$. Grows in presence of $3-7 \% \mathrm{NaCl}$. The $\mathrm{pH}$ range for growth is 6-11 and the optimum is $\mathrm{pH} 9$. Catalase-positive and oxidase-negative. Acid is produced from D-galactose and L-rhamnose; no acid is produced from D-xylose, inositol or D-lactose; acid production for erythritol, D-adonitol and D-glucose is weak. Using the API CORYNE and API ZYM systems, positive reactions are observed for pyrazinamidase, pyrrolidonyl arylamidase, $\alpha$-glucosidase, $\beta$-glucuronidase, $\beta$-galactosidase, urease, esterase lipase (C8), leucine arylamidase, valine arylamidase, cystine arylamidase, trypsin, naphthol-AS-BI-phosphohydrolase, $\beta$-glucosidase, alkaline phosphatase, $N$ acetyl- $\beta$-glucosaminidase, $\alpha$-chymotrypsin and $\alpha$-mannosidase. No activity is detected for nitrate reductase, esterase (C4), $\alpha$-galactosidase, lipase (C14) or $\alpha$-fucosidase; gelatin hydrolysis and acid phosphatase are weak. The predominant fatty acid is iso- $\mathrm{C}_{16: 0}$. The major menaquinone is MK- $9\left(\mathrm{H}_{4}\right)$. The $\mathrm{G}+\mathrm{C}$ content of the DNA of the type strain is $72.4 \mathrm{~mol} \%$.

The type strain is strain $\mathrm{LC}_{11}{ }^{\mathrm{T}}\left(=\mathrm{IAM} 15388^{\mathrm{T}}=\mathrm{CCTCC}\right.$ AB206020 ${ }^{\mathrm{T}}$ ), which was isolated from a filtration substrate made from volcanic soil, Niigata, Japan.

\section{Acknowledgements}

We thank Professor Dr Hans G. Trüper and Dr Jean Euzéby for their help regarding the Latin nomenclature.

\section{References}

Ding, L. \& Yokota, A. (2002). Phylogenetic analysis of the genus Aquaspirillum based on 16S rRNA gene sequences. FEMS Microbiol Lett 212, 165-169.

Ding, L. \& Yokota, A. (2004). Proposals of Curvibacter gracilis gen. nov., sp. nov. and Herbaspirillum putei sp. nov. for bacterial strains isolated from well water and reclassification of [Pseudomonas] huttiensis, [Pseudomonas] lanceolata, [Aquaspirillum] delicatum and [Aquaspirillum] autotrophicum as Herbaspirillim huttiense comb. nov., Curvibacter lanceolatus comb. nov., Curvibacter delicatus comb. nov. and Herbaspirillum autotrophicum comb. nov. Int J Syst Evol Microbiol 54, 2223-2230.

Embley, T. M., Smida, J. \& Stackebrandt, E. (1988). The phylogeny of mycolate-less wall chemotype IV actinomycetes and description of Pseudonocardiaceae fam. nov. Syst Appl Microbiol 11, 44-52.

Ezaki, T., Hashimoto, Y. \& Yabuuchi, E. (1989). Fluorometric deoxyribonucleic acid-deoxyribonucleic acid hybridization in microdilution wells as an alternative to membrane filter hybridization in which radioisotopes are used to determine genetic relatedness among bacterial strains. Int J Syst Bacteriol 39, 224-229. 
Felsenstein, J. (1981). Evolutionary trees from DNA sequences: a maximum likelihood approach. J Mol Evol 17, 368-376.

Felsenstein, J. (1985). Confidence limits on phylogenies: an approach using the bootstrap. Evolution 39, 783-791.

Felsenstein, J. (1993). PHYLIP (phylogeny inference package) version 3.5c. Distributed by the author. Department of Genome Sciences, University of Washington, Seattle, USA.

Hasegawa, T., Takizawa, M. \& Tanida, S. (1983). A rapid analysis for chemical grouping of aerobic actinomycetes. J Gen Appl Microbiol 29, 319-322.

Huang, Y., Qi, W., Lu, Z., Liu, Z. \& Goodfellow, M. (2001). Amycolatopsis rubida sp. nov., a new Amycolatopsis species from soil. Int J Syst Evol Microbiol 51, 1093-1097.

Kimura, M. (1980). A simple method for estimating evolutionary rates of base substitutions through comparative studies of nucleotide sequences. J Mol Evol 16, 111-120.

Kroppenstedt, R. M. (1985). Fatty acid and menaquinone analysis of actinomycetes and related organisms. In Chemical Methods in Bacterial Systematics, pp. 173-199. Edited by M. Goodfellow \& D. E. Minnikin. London: Academic Press.

Lechevalier, M. P. \& Lechevalier, H. A. (1970). Chemical composition as a criterion in the classification of aerobic actinomycetes. Int J Syst Bacteriol 20, 435-443.

Lechevalier, H. A. \& Lechevalier, M. P. (1980). The chemotaxonomy of actinomycetes. In Actinomycete Taxonomy (Society for Industrial Microbiology Special Publication no. 6), pp. 277-284. Edited by A. Dietz \& D. W. Thayer. Arlington, VA: Society for Industrial Microbiology.

Lechevalier, M. P., Prauser, H., Labeda, D. P. \& Ruan, J. S. (1986). Two new genera of nocardioform actinomycetes: Amycolata gen. nov. and Amycolatopsis gen. nov. Int J Syst Bacteriol 36, 29-37.

Lee, S. D. \& Hah, Y. C. (2001). Amycolatopsis albidoflavus sp. nov. Int J Syst Evol Microbiol 51, 645-650.

Majumdar, S., Prabhagaran, S. R., Shivaji, S. \& Lal, R. (2006). Reclassification of Amycolatopsis orientalis DSM 43387 as Amycolatopsis benzoatilytica sp. nov. Int J Syst Evol Microbiol 56, 199-204.

Mesbah, M., Premachandran, U. \& Whitman, W. B. (1989). Precise measurement of the $\mathrm{G}+\mathrm{C}$ content of deoxyribonucleic acid by highperformance liquid chromatography. Int J Syst Bacteriol 39, 159-167.
Minnikin, D. E., Hutchinson, I. G., Caldicott, A. B. \& Goodfellow, M. (1980). Thin layer chromatography of methanolysates of mycolic acid-containing bacteria. J Chromatogr 188, 221-233.

Minnikin, D. E., O'Donnell, A. G., Goodfellow, M., Alderson, G., Athalye, M., Schaal, A. \& Parlett, J. H. (1984). An integrated procedure for the extraction of bacterial isoprenoid quinones and polar lipids. J Microbiol Methods 2, 233-241.

Saitou, N. \& Nei, M. (1987). The neighbor-joining method: a new method for reconstructing phylogenetic trees. Mol Biol Evol 4, 406-425.

Sambrook, J., Fritsch, E. F. \& Maniatis, T. (1989). Molecular Cloning: a Laboratory Manual, 2nd edn. Cold Spring Harbor, NY: Cold Spring Harbor Laboratory.

Sasser, M. (1990). Identification of bacteria by gas chromatography of cellular fatty acids. MIDI Technical Note 101. Newark, DE: MIDI Inc.

Staneck, J. L. \& Roberts, G. D. (1974). Simplified approach to identification of aerobic actinomycetes by thin-layer chromatography. Appl Microbiol 28, 226-231.

Thompson, J. D., Gibson, T. J., Plewniak, F., Jeanmougin, F. \& Higgins, D. G. (1997). The CLUSTAL_X windows interface: flexible strategies for multiple sequence alignment aided by quality analysis tools. Nucleic Acids Res 25, 4876-4882.

Warwick, S., Bowen, T., McVeigh, H. \& Embley, T. M. (1994). A phylogenetic analysis of the family Pseudonocardiaceae and the genera Actinokineospora and Saccharothrix with $16 \mathrm{~S}$ rRNA sequences and a proposal to combine the genera Amycolata and Pseudonocardia in an emended genus Pseudonocardia. Int J Syst Bacteriol 44, 293-299.

Wayne, L. G., Brenner, D. J., Colwell, R. R., Grimont, P. A. D., Kandler, O., Krichevsky, M. I., Moore, L. H., Moore, W. E. C., Murray, R. G. E. \& other authors (1987). International Committee on Systematic Bacteriology. Report of the ad hoc committee on reconciliation of approaches to bacterial systematics. Int J Syst Bacteriol 37, 463-464.

Willems, A., Doignon, B. F., Goris, J., Coopman, R., de Lajudie, P., De Vos, P. \& Gillis, M. (2001). DNA-DNA hybridization study of Bradyrhizobium strains. Int J Syst Evol Microbiol 51, 1315-1322.

Yano, I., Saito, K., Fukukawa, Y. \& Kusunose, M. (1972). Structural analysis of molecular species of nocardomycolic acids from Nocardia erythropolis by the combined system of gas chromatography and mass spectrometry. FEBS Lett 21, 215-219. 